\title{
Strategi Pemasaran UMKM Untuk Bertahan dan Berkembang Di Masa Pandemi Covid-19 (Studi di Desa Tawang Kecamatan Wates Kabupaten Kediri)
}

\author{
Carista Nora Melinda ${ }^{1}$, Khoiru Nidak ${ }^{2}$ \\ Perbankan Syariah Islam, Institut Agama Islam Negeri Kediri ${ }^{1,2}$ \\ email: Carista.nora07@gmail.com ${ }^{1}$
}

\begin{abstract}
Abstrak
Pademi Covid-19 yang saat ini terjadi di berbagai negara termasuk di Indonesia membuat sektor perekonomian menurun drastis, khususnya pada kegiatan UMKM. Saat ini pemerintah menerapkan PPKM (Pemberlakuan Pembatasan Kegiatan Masyarakat di Indonesia) di Jawa dan Bali. Jawa Timur termasuk salah satu yang menerapkan kebijakan PPKM secara ketat. Diberlakukannya PPKM membuat kegiatan perekonomian masyarakat menjadi terhambat, dikarenakan pembatasan dan penyekatan hamper seluruh akses utama jalan yang disepanjang jalan tersebut banyak pedagang yang berjualan, tetapi sekarang terpaksa tutup karena adanya PPKM. UMKM atau yang biasa kita sebut dengan Usaha Mikro Kecil Menengah yang jelas terkena dampaknya yang sangat signifikan, pendapatan yang diperoleh pasti mengalami penurunan. Tidak sedikit juga UMKM yang harus tidak berjualan terlebih dahulu karena efek dari dampak covid-19 ini. Strategi pemasaran harus diterapkan oleh semua UMKM agar dagangannya mendapatkan omzet yang stabil walaupun adanya dampak dari covid-19. Tidak sedikit juga UMKM yang masih berhasil mempertahankan usahanya dan masih memiliki omzet yang stabil saat adanya pandemi covid-19 ini. Walaupun saat ini masih adanya pandemik covid-19 tetapi UMKM harus terus bertahan dan berkembang pada saat seperti ini, harus adanya inovasi-inovasi atau dobrakan baru agar UMKM yang dijalankan terus berkembang dan selalu bertahan walaupun saat ini lagi pandemi covid-19.
\end{abstract}

Kata kunci: UMKM, Pemasaran.

\section{Abstract}

The Covid-19 pandemic that is currently happening in various countries, including Indonesia, has made the economic sector decline drastically, especially in the activities of MSMEs. Currently the government is implementing PPKM (Enforcement of Restrictions on Community Activities in Indonesia) in Java and Bali. East Java is one that implements the PPKM policy strictly. The implementation of PPKM has hampered the community's economic activities, due to restrictions and blocking of almost all main access roads along the road, many traders selling, but now they are forced to close because of PPKM. MSMEs, or what we usually call Micro, Small and Medium Enterprises, are clearly affected by a very significant impact, the income earned must experience a decline. Not a few MSMEs also have to not sell first because of the effects of this Covid-19 impact. Marketing strategies must be implemented by all MSMEs so that their merchandise gets a stable turnover despite the impact of COVID-19. Not a few MSMEs have still managed to maintain their business and still have a stable turnover during this COVID-19 pandemic. Even though there is currently a COVID-19 pandemic, MSMEs must continue to survive and develop at a time like this, there must be new innovations or breakthroughs so that MSMEs that are run continue to grow and always survive even though there is currently a COVID-19 pandemic.

Keywords: UMKM, Marketing.

\section{Pendahuluan}

UMKM (Usaha Mikro Kecil Menengah) yaitu usaha ekonomi produktif yang dimilki perorangan maupun badan usaha sesuai dengan kriteria yang ditetapkan. UMKM ini termasuk dalam jenis usaha produktif yang hingga saat ini perkembangannya di Indonesia perkembangannya sangat pesat. ${ }^{1}$ Tetapi saat adanya pandemic covid-19 ini perkembangan UMKM di Indonesia khususnya Desa Tawang mengalami penurunan. Dengan terus bertambahnya orang yang terkena covid-19 maka pemerintah

\footnotetext{
${ }^{1}$ Fadilah Nur Azizah, "Strategi UMKM untuk Meningkatkan Perekonomian Selama Pandemi Covid-19 Pada Saat New Normal”, Jurnal of Economics, Vol. 5, No. 1, Desember 2020, 46-47.
} 
memberlakukan PPKM, kebijakan seperti ini sebenarnya sangat menyusahkan dan merugikan pihak UMKM di Desa Tawang, karena pelaku UMKM tidak bisa berjualan seperti biasanya. Tetapi pelaku UMKM tidak kehabisan akal untuk selalu bertahan dan berkembang di masa pandemic covid-19 pada saat ini.

Desa Tawang selalu menciptakan inovasi-inovasi baru khusunya pelaku UMKM yang ada di dalam Desa Tawang tersebut. Apalagi dengan adanya dampak covid-19 pada saat ini pelaku UMKM di Desa Tawang baik UMKM makanan ataupun bahan makanan sekarang hampir 30\% orang sudah memasarkan produknya di Marketplace dan $70 \%$ nya memasarkan produknya di pasar tradisional yang berada di Desa Tawang. Program yang dilakukan desa adalah mendata mana saja UMKM yang masih menjadi UMKM kecil dan masih berjualan di pasar ataupun yang sudah gulung tikar akibat adanya dampak covid-19 seperti saat ini. Program yang dilakukan desa dengan mendata pelaku UMKM yang tersebar di desa Tawang yang nantinya akan mendapatkan penyuluhan, bantuan dana, dan pelatihan menggunakan media digital khusunya Marketplace untuk menjual dagangannya.

Berdasarkan hasil observasi dan wawancara yang dilakukan di Desa Tawang bahwa jumlah UMKM yang ada di Desa Tawang sebanyak 6 UMKM dan 30\% diantaranya sudah menggunakan Marketplace sebagai media untuk menjual dagangannya dan selain itu dijual dipasar, dijajakan keliling dan ada juga yang langsung diambil oleh pengepul.

Wabah covid-19 ini memberi dampak sekali pada usaha UMKM karena banyak pelaku UMKM yang mengeluh karena ada dampak covid-19 dan sekarang kebijakan pemerintah adanya PPKM yang menyebabkan pelaku UMKM banyak yang menjadi sepi dagangannya dan ada juga yang sampai gulung tikar alias bangkrut. Perbedaan keuntungan usaha yang diperoleh sebelum adanya covid-19 dan sesudah adanya covid-19 presentase nya sangat jauh menurun. Hampir semua UMKM yang saya wawancarai hanya bertahan dulu dan ada juga yang tidak produksi dan hanya menghabiskan stok yang tersisa dulu baru membuat lagi. Ada juga UMKM yang harus memperhentikan sebagian karyawannya karena sudah tidak mampu mengaji karyawannya karena pendapatan usahanya sudah menurun. Apalagi saat ini PPKM yang membuat hampir semua UMKM mengeluh karena dagangan menjadi sepi bahkan tidak laku. Usaha UMKM di Desa Tawang khusunya Dusun Semanding juga mengeluh karena adanya PPKM yang dulunya bisa mengirim barang ke luar kota, sekarang sudah tidak bisa. Akhirnya pelaku UMKM hanya bisa bertahan di masa pandemi covid-19 apalagi saat ini sedang adanya PPKM. Pelaku UMKM yang sudah saya wawancarai hampir semua melakukan strategi dan pemikiran baru untuk terus selalu bertahan dan berkembang usahanya di masa pandemi covid-19 saat ini. Strategi-strategi baru terus dilakukan agar pihak UMKM dapat bertahan di masa pandemi.

Dalam menghadapi pandemi covid-19 saat ini pelaku UMKM sudah mendapatkan ide-ide baru agar usahanya dapat terus bertahan di masa pandemic covid-19. Maka diperluhkan model terbaru oleh pelaku UMKM untuk memasarkan usahanya yaitu dengan kemajuan teknologi pada saat ini. Dalam hal ini teknologi digital memiliki pengaruh yang signifikan terhadap kelancaran UMKM di masa pandemi covid-19. Dalam upaya pengembangan UMKM digital perluh diperhatikan kualitas produksi dan kapasitas produksi. ${ }^{2}$

Solusi yang bisa diberikan agar pelaku UMKM dapat bertahan dan selalu berkembang di masa pandemic covid-19 ini yaitu dengan memanfaatkan teknologi digital yang saat ini sudah banyak kita jumpai pada kehidupan sehari-hari. Bisa menjual dagangannya di Marketplace, shopee, dll. Tetapi pelaku UMKM harus selalu memperhatikan kualitas produknya jika dijual di Markeplace harus diberi keterangan jika produk itu makanan jadi yang hanya bisa bertahan sebentar maka harus diberikan keterangan jika pengiriman yang jauh tidak bisa, agar menghindari jika produk tersebut akan basi jika lama di pengiriman. Jika itu bahan mentah pelaku UMKM harus selalu memperhatikan kapasitas produknya. Agar tidak ada kerugiaan baik pelaku UMKM ataupun pembeli.

\subsection{KAJIAN PUSTAKA}

\section{A. Pemasaran}

1) Pengertian Pemasaran

Pemasaran yaitu suatu sistem total dari kegiatan bisnis yang dirancang untuk merencanakan, menentukan harga, promosi, dan mendistribusikan barang-barang yang

\footnotetext{
2 Bambang Arianto," Pengembangan UMKM Digital Di Masa Pandemi Covid-19”, Jurnal Administrasi Bisnis, Vol. 6, No. 2, Desember 2020, 234-235.
} 
dapat memuaskan keinginan. ${ }^{3}$ Menurut Kotler dan Amstrong (2008) pemasaran yaitu analisis, perencanaan, implementasi, dan pengendalian dari program-program yang dirancang untuk menciptakan, membangun, dan memelihara pertukaran yang menguntungkan dengan pembeli sasaran untuk mencapai tujuan dari perusahaan. ${ }^{4}$

2) Strategi Pemasaran

Terdapat beberapa macam pengertian strategi dari para ahli menurut Marrus Umar (2017) trategi didefinisikan sebagai suatu proses penentuan rencana para pemimpin puncak yang berfokus pada tujuan jangka panjang organisasi, disertai penyusunan suatu cara atau upaya bagaimana agar tujuan tersebut dapat dicapai. Strategi didefinisikan khusus sebagai tindakan yang bersifat incremental (senantiasa meningkat) dan terus-menerus, serta dilakukan berdasarkan sudut pandang tentang apa yang diharapkan oleh para pelanggan di masa depan.

Menurut Chandra (2011) strategi pemasaran yaitu rencana yang menjabarkan ekspetasi perusahaan akan dampak berbagai aktifitas atau program pemasaran terhadap permintaan produk atau lini produknya di pasar sasaran tertentu. ${ }^{5}$ Menurut Kloter (2007) bahwa strategi pemasaran sebagai seperangkat alat pemasaran teknis yang dapat dikendalikan, yang dipadukan oleh perusahaan untuk menghasilkan respons yang diinginkan dalam pasar sasaran. Strategi pemasaran meliputi:

a. Produk

Menurut Kloter dan Kelle (2007) produk adalah segala sesuatu yang dapat ditawarkan ke pasar untuk diperhatikan, dimiliki, digunakan atau dikonsumsi sehingga dapat memuaskan kebutuhan dan keinginan konsumen.

b. Harga

Harga merupakan satu-satunya unsur bauran pemasaran yang memberikan pemasukan atau pendapatan bagi perusahaan, disamping itu merupakan unsur bauran pemasaran bersifat fleksibel (dapat cepat diubah).

c. Promosi

Promosi merupakan salah satu perubah di dalam bauran pemasaran yang sangat penting dilaksanakan oleh perusahaan dalam memasarkan produknya. Betapapun bagusnya suatu produk, bila konsumen belum pernah mendengarnya dan tidak yakin produk itu akan berguna bagi mereka, maka mereka tidak akan membeli produk tersebut. Pada dasarnya promosu adalah semua kegiatan yang bermaksud mengomunikasikan atau menyampaikan suatu produk kepada pasar sasaran untuk memberikan informasi tentang keistimewaan, kegunaan, dan yang paling penting adalah tentang keberadaannya untuk mengubah sikap ataupun untuk mendorong orang untuk bertindak (dalam hal ini membeli produk tersebut).

d. Lokasi

Menurut Kloter (2007) adalah suatu strategi yang menentukan dimana dan bagaimana kita menjual suatu produk tertentu.

\section{B. Definisi Bertahan dan Berkembang}

Definisi bertahan yang dikutip dari www.id.m.wiktionary.org yaitu tetap pada tempatnya, tidak mau menyerah, berteguh hati dan berkeras hati. Jadi bertahan adalah sesuatu tindakan yang dilakukan seseorang untuk mempertahankan sesuatu yang sudah menjadi kehendaknya. ${ }^{6}$

\footnotetext{
${ }^{3}$ Ade Priagani, "Memperkuat Manajemen Pemasaran dalam Konteks Persaingan”, Jurnal Kebangsaan, Vol. 2, No. 4, Juli 2013, 2.

${ }^{4}$ Masnia Mahardi Yanuar, Dampak Kualitas Produk, Harga, Promosi, Dan Kualitas Pelayanan Terhadap Kepuasan Pelanggan Optik Marlin Cabang Jember, Jurnal Manajemen Dan Bisnis Indonesia, Vol. 3, No. 1, Juni 2017, 65.

${ }^{5}$ Dimas Hendika Wibowo, "Analisis Strategi Pemasaran Untuk Meningkatkan Daya Saing UMKM (Studi pada Bati Diajeng Solo)”, Jurnal Administrasi Bisnis (JAB), Vol. 29, No. 1, Desember 2015, 60-61.

${ }^{6}$ Definisi Bertahan, diakses di Kediri pada Tanggal 25 Juli 2021, Pukul 10:12 dari

http://www.id.m.wiktionanary.org/wiki/bertahan
} 
Sedangkan definisi berkembang yang dikutip dari www.kbbi.web.id yaitu menjadi besar dan menjadi banyak. Jadi berkembang adalah sesuatu yang bisa menjadi besar dan banyak jika dilakukan dengan niat yang sungguh-sungguh. ${ }^{7}$

C. Media Sosial

Media sosial merupakan media yang menawarkan digitisation, convergence, interacitivy, dan development of networl terkait pembuatan pesan dan penyampaian pesannya. Media sosial adalah sebuah media online, dengan para penggunanya bisa dengan mudah berpartisipasi, berbagi dan menciptakan isi meliputi blog, jejaring sosial, wiki, forum dan dunia virtual. $^{8}$

D. Marketplace

Definisi marketplace yang dikutip dari www.niagahoster.co.id adalah perantara antara penjual dan pembeli di dunia maya. Situs marketplace bertindak sebagai pihak ketiga dalam transaksi online dengan menyediakan tempat berjualan dan fasilitas pembayaran. Bisa dikatakan marketplace adalah deparment store online. Jenis-jenis marketplace ada 2 yaitu: ${ }^{9}$

1) Marketplace Murni

Ketika situs marketplace hanya menyediakan lapak untuk berjualan dan fasilitas pembayaran. Penjual yang melakukan kerjasama marketplace diberikan keleluasaan lebih banyak dibandingkan kerjasama konsinyasi. Contohnya adalah Tokopedia, Bukalapak, Elvenia, Blanja, Blibi, Shopee, Lazada, JD.ID, Amazon dan Rakuten.

2) Marketplace Konsinyasi

Titip barang. Jika penjual melakukan kerjasama konsinyasi dengan situs marketplace, ia hanya perluh menyediakan produk dan detail informasi kepada pihak marketplace. Contohnya Zalora dan Berrybenka.

\section{E. Daya Beli Konsumen}

Keterkaitan konsumen untuk memiliki suatu produk ditentukan oleh beberapa faktor, diantaranya kualitas, produk, spesifikasi, dan harga. Seiring dengan berkembangnya ilmu pengetahuan dan teknologi informasi, maka konsumen sangat dimudahkan adanya internet yang mampu menyediakan segala kebutuhan manusia terkait dengan produk yang mereka inginkan. ${ }^{10}$

\section{F. Definisi UMKM}

Pemerintah sendiri telah menetapkan pengertian UMKM dan kriterianya. Arti UMKM tersebut tertuang dalam UU Nomor 20 Tahun 2008 tentang Usaha Mikro, Kecil, dan Menengah. Dikutip dari www.Kompas.com UMKM artinya sebagai bisnis yang dijalankan individu, rumah tangga, atau badan usaha ukuran kecil. Penggolongan UMKM lazimnya dilakukan dengan batasa omzet per tahyn, jumlah kekayaan atau asset, serta jumlah karyawan. ${ }^{11}$

Di tanah air, UMKM memiliki peran sangat penting dalam perekonomian negara. Ini karena sektor UMKM adalah penymbang PDB terbesar, paling banyak menyerap lapangan kerja, serta relative tahan terhadap krisis keuangan. Jenis UMKM di Indonesia:

1) Usaha Mikro

Usaha mikro UMKM adalah usaha produktif milik orang perorangan dan/ badan usaha perorangan memenuhi kriteria usaha mikro sebagai diatur dalam UU tersebut.

2) Usaha Kecil

\footnotetext{
${ }^{7}$ Definisi Berkembang, diakses di Kediri pada Tanggal 25 Juli 2021, Pukul 10:33 dari https://www.google.com/amp/s/kbbi.web.id/berkembang.html

${ }^{8}$ Errika Dwi Setya Watie, “Komunikasi dan Media Sosial, Jurnal The Messenger”, Vol. 3, No. 1, Juli 2011, 7071.

${ }^{9}$ Marketplace, diakses di Kediri pada Tanggal 25 Juli 2021, Pukul 13:53 dari https://www.google.com/amp/s/www.niagahoster.co.id/blog/marketplace-adalah/

${ }^{10}$ Maskarto Lucky Nara Rosmadi, "Penerapan Strategi Bisnis di Masa Pandemi Covid-19”, Jurnal IKRA-ITH Ekonomika, Vol. 4, No. 1, Maret 2021, 124.

${ }^{11}$ UMKM, diakses di Kediri pada Tanggal 25 Juli 2021, Pukul 14:27 dari

https://money.kompas.com/read/2021/03/36/153202726/apa-itu-umkm-pengertian-kriteria-dancontohnya?page=all\#page 2
} 
Usaha Kecil adalah usaha ekonomi produktif yang berdiri sendiri, dilakukan oleh orang perorangan atau badan usaha yang bukan anak perusahaan atau bukan cabang perusahaan yang dimiliki, dikuasai, atau menjadi bagian baik langsung atau tidak langsung dari usaha menengah atau usaha besar yang memenuhi kriteria usaha kecil yang dimaksud dalam UU. Contohnya UMKM kecil adalah usaha binatu, restoran kecil, bengkel montor, ketering, usaha fotocopy, dan sebagainya.

3) Usaha Menengah

Sementara usaha menengah adalah usaha ekonomi produktif yang berdiri sendiri, yang dilakukan oleh orang perorangan atau badan usaha yang bukan merupakan anak perusahaan atau cabang perusahaan yang dimiliki, dikuasai atau menjadi bagian langsung maupun tidak langsung dengan usaha kecil atau usaha besar dengan jumlah kekayaan bersih atau hasil penjualan tahunan sebagaimana diatur dalam UU tersebut. Contoh UMKM menengah adalah perusahaan pembuatan roti skala rumahan, restoran besar, hingga toko bangunan.

\section{METODE PENELITIAN}

Penelitian ini dilakukan di beberapa UMKM yang berada di Desa Tawang Kecamatan Wates Kabupaten Kediri adapun pelaksanaan penelitian ini dilakukan dari bulan Juli tanggal 05 sampai tanggal 24 Juli 2021. Metode yang digunakan adalah metode kualitatif dengan pendekatan deskriptif. Jenis data yang diperoleh adalah data primer yang diperoleh langsung dari hasil wawancara, dokumentasi dan observasi. Populasi dan sampel yaitu UMKM masyarakat di Desa Tawang ada sebanyak 5 UMKM.

\section{HASIL DAN PEMBAHASAN}

a. Bagaimana cara pelaku UMKM Desa Tawang Kecamatan Wates Kabupaten Kediri bertahan di masa Pandemi Covid-19

Pelaku UMKM yang berada di Desa Tawang Kecamatan Wates Kabupaten Kediri juga hampir semua mengeluh karena omset yang semula tinggi akhirnya ikut menurun akibat adanya pandemic covid-19 yang terjadi hampir lebih dari satu tahun ini. Pelaku UMKM yang dulunya mempunyai pegawai yang lumayan banyak sekarang harus mengurangi pegawainya. Apalagi saat ini diterapkannya PPKM yang saat ini sangat merugikan pelaku UMKM yang akan mengirimkan produksinya sendiri ke luar kota sekarang sudah tidak bisa dan akhirnya hanya menghabiskan stok yang masih dan belum berani produksi yang banyak, karena pelaku UMKM takut produknya tidak laku.

Tetapi dari sebagian pelaku UMKM yang saya wawancarai hanya sebagian saja yang sudah menggunakan media sosial sebagai cara memasarkan produknya. Ada juga yang tetap keliling dan menjajakan produknya dipasar tetapi dengan harga yang beda sebelum adanya covid-19. Hampir semua UMKM menurunkan harga produknya saat ini. Itu adalah strategi yang dilakukan pelaku UMKM di Desa Tawang agar tetap bertahan pada saat pandemic covid-19 pada saat ini.

Dari hasil wawancara yang dilakukan banyak pelaku UMKM yang mempunyai berbagai cara agar tetap bisa mempertahankan usahanya di tengah pandemic seperti saat ini. Cara yang dilakukan oleh pelaku UMKM adalah dengan memasarkan produknya di media sosial dan menurunkan harga yang semula menjadi harga yang lebih murah. Cara seperti itu dilakukan pelaku UMKM agar usahanya tetap bisa bertahan dan selalu berkembang di saat pandemic saat ini. Hampir semua UMKM yang ada di Desa Tawang juga menurunkan harga produknya untuk selalu bertahan pada saat ini. Juga ada yang memasarkan produknya di media sosial seperti halnya marketplace yang saat ini dimanfaatkan oleh pelaku UMKM yang terdampak akibat adanya pandemi covid-19 pada saat ini. Tetapi tidak semua pelaku UMKM yang merasakan dampak dari pandemic covid-19 ada juga UMKM salah satunya yang berada di Desa Tawang Kecamatan Wates Kabupaten Kediri yang walaupun saat ini sedang adanya pandemic covid-19 namun usahanya tetap bertahan dan bahkan berkembang di masa saat ini. Saat wawancara pelaku UMKM menjelaskan bahwa tidak merasakan dampak dari pandemic ini malah kadang kewalahan karena pesanan yang cukup banyak dari para pendagang keliling yang mengambil barang, strategi yang dilakukan pelaku UMKM tersebut yaitu hampir sama dengan pelaku UMKM lain menurunkan harga produknya sebelum dan sesudah adanya pandemic covid-19. 
Pelaku UMKM di Desa Tawang yang sudah saya wawancarai yang sudah menggunakan media sosial sebagai sarana untuk memasarkan produknya di saat pandemic covid-19 saat ini adalah Pia Kering Matahari dan Pabrik Gula Tebu. Sedangkan pelaku UMKM yang menjajakan dagangannya keliling dan menurunkan harga produknya adalah Es Puter dan Penggorengan Krupuk. Ada juga pelaku UMKM di Desa Tawang walaupun sedang kondisi covid-19 saat ini namun usahanya tetap berkembang adalah Pabrik Tahu.

Data yang diperoleh saat melakukan wawancara dan pengamatan UMKM di Desa Tawang Kecamatan Wates Kabupaten Kediri dapat diperoleh bahwa semua UMKM masih bisa bertahan di masa pandemic dengan berbagai cara yang dilakukan oleh pelaku UMKM untuk selalu dan tetap mempertahankan usahanya walaupun saat ini sedang terjadi pandemic covid-19. Dari hasil wawancara dan pengamatan pada UMKM di Desa Tawang semua UMKM menurunkan harga jual produknya agar tetap selalu bertahan pada saat ini. UMKM di Desa Tawang yang mempertahankan produknya dengan memanfaatkan media sosial itu sebanyak $30 \%$ yaitu meliputi penjual pia matahari kering, gula tebu, dll dan yang $70 \%$ yaitu meliputi es puter, penggorengan krupuk, pabrik tahu, dll yang saat ini berjualan keliling dan berjualan di pasar tetapi harga produknya sama-sama dikurangi. Alasan yang diperoleh saat melakukan wawancara yaitu agar saat ini UMKM yang dilakukan tetap bertahan dan selalu berkembang terus.

b. Apa strategi pelaku UMKM untuk mengembangkan usahanya di masa Pandemi Covid19

Strategi yang dilakukan pelaku UMKM untuk untuk mengembangkan usahanya di masa pandemic covid-19 saat ini yaitu:

a. Adanya diskon yang diberikan oleh pelaku UMKM

Dengan adanya harga diskon ataun penurunan harga makan pelaku UMKM dapat menilai bahwa produk dihargai segitu dengan untuk yang sedikit tetapi pelanggan selalu berdatangan, atau harga normal tetapi sepi. Pelaku UMK pasti akan memilih mendiskon produknya agar pembeli selalu berdatangan untuk membeli produknya tersebut.

b. Mempertahankan pelanggan lama

Saat ini memepertahankan pelanggan lama sangat diperluhkan karena pelanggan lama akan kembali lagi membeli produk yang sudah mereka beli karena mengetahui kualitas dari produk tersebut. Besar kemungkinan pelanggan lama tersebut akan mengajak temannya untuk membeli produk karena mengetahui kualitas produk yang bagus dan dengan harga yang relatif murah disbanding dengan UMKM yang lainnya.

c. Inovasi bisnis

Inovasi bisnis saat ini juga perluh dilakukan pelaku UMKM dalam mengembangkan produknya di masa pandemic covid-19 ini. Karena dengan inovasi-inovasi bisnis baru yang dilakukan pelaku UMKM dalam mengembangkan produknya maka lebih baik juga dalam mengembangkan produk UMKM tersebut dan bisa bersaing dipasaran dan UMKMnya dapat bertahan dan berkembang walaupun adanya pandemic covid-19 ini.

Beberapa strategi yang sudah dilakukan pelaku UMKM di Desa Tawang Kecamatan Wates Kabupaten Kediri adalah sebagai berikut:

a. Memanfaatkan sisi positif dari teknologi untuk menyebarluaskan produk

Yakni memasarkan produk melalui media sosial, salah satunya menawarkan produk di Marketplace Facebook, Shopee, Bukalapak, Tokopedia, membagikan di setiap kontak Whatsapp, dan dalam penyampaiannya menggunakan bahasa yang menarik dan pastinya bahasa yang santun.

b. Adanya pengurangan harga

Pengurangan harga dilakukan agar konsumen lebih tertarik untuk membeli produk tersebut. Penjual saat ini tidak memikiran untung yang besar, yang terpenting usahanya dapat bertahan di tengah pandemic covid-19, apalagi saat ini diterapkannya PPKM, jadi pelaku UMKM harus berpikir keras bagaimana usahanya bisa tetap bertahan di masa seperti saat ini. Salah satu keputusan yang diambil pelaku UMKM yang berada di Desa Tawang Kecamatan Wates Kabupaten Kediri adalah penggurangan harga produknya. 
Strategi pelaku UMKM untuk mengambangkan usahanya pada UMKM di Desa Tawang Kecamatan Wates Kabupaten Kediri ini menurut hasil wawancara yang sudah dilakukan pelaku UMKM sudah mengembangkan usahanya di tengah pandemic covid-19 saat ini. Penurunan harga dan inovasi-inovasi baru terus dilakukan agar pelaku UMKM bisa selalu bertahan dan berkembang di masa pandemic covid-19 seperti saat ini.

Dari hasil wawancara yang dilakukan inovasi-inovasi baru yang dilakukan UMKM di Desa Tawang Kecamatan Wates Kabupaten Kediri yaitu antara lain:

a. Memasarkan produknya ke media sosial atau ke Marketplace

b. Menciptakan packingan yang menarik agar konsumen lebih bisa tertarik untuk membeli produk tersebut.

c. Adanya Buy 2 Free 1 itu dilakukan di UMKM Es Putet yang menerapkan inovasi seperti itu.

\section{c. Apa strategi pemasaran yang efektif dilakukan oleh pelaku UMKM di masa Pandemi} Covid-19

Strategi pemasaran yang dilakukan pelaku UMKM di masa pandemic covid-19 adalah dengan memanfaatkan Marketplace. Disini masyarakat hampir 90\% menggunakan Marketplace untuk membeli produk. Marketplace ini jika dikembangkan oleh pelaku UMKM untuk menjual produknya maka akan benar-benar membawa perubahan untuk produk tersebut dan pelaku UMKM bisa bertahan di masa pandemic covid-19 pada saat ini. Marketplace adalah tempat belanja yang saat ini sedang di minati masyarakat di Indonesia yaitu contohnya Shopee, Bukalapak dan Tokopedia. Pelaku UMKM bisa memasarkan produknya dengan tetap melihat kualitas produk dan kapasitas produknya seperti apa. Marketplace banyak sekali dan tidak hanya itu saja, bisa juga jika produknya itu cepat basi digunakan sistem COD yang hanya beberapa jam aja langsung sampai ke tempat konsumen.

Pada dasarnya pelaku UMKM pada saat ini selalu berpikir keras agar mampu mengembangkan usahanya di masa pandemic covid-19 pada saat ini. Strategi pemasaran yang efektif yaitu antara lain:

a. Memberikan Potongan Harga

Potongan harga yang dilakukan pelaku UMKM pada saat ini sangat berpengaruh terhadap perkembangan usaha UMKM tersebut. Pada saat adanya pandemic covid-19 pada saat ini karena orang-orang akan lebih tertarik untuk membeli karena harganya yang saat ini sangat bersahabat. Itu strategi yang sangat pintar yang dilakukan oleh pelaku UMKM dalam memanfaatkan kondisi seperti ini.

b. Melakukan Promosi di Media Sosial

Promosi yang dilakukan pelaku UMKM di media sosial saat ini sangat bermanfaat karena sekarang media sosial menjadi salah satu alternatif masyarakat dalam berbelanja yang tidak mau keluar rumah karena menghindari kerumunan di luar, dengan media sosial barang yang kita inginkan bisa dengan mudah sampai dirumah. Pelaku UMKM yang mempromosikan produknya di media sosial juga harus memperhatiakan kualitas produknya dan kapasitas produknya. Saat pandemic seperti ini media sosial sangat di manfaat oleh pelaku UMKM agar usahanya tetap bertahan dan bahkan berkembang walaupun adanya pandemic covid19 ini. Teknologi yang berkembang pada saat ini sangat efektif di manfaatkan oleh pelaku UMKM yang saat ini usahanya terdampak pandemic covid-19.

Strategi pemasaran yang dilakukan oleh pelaku UMKM di Desa Tawang Kecamatan Wates saat adanya pandemic covid-19 ini sudah sangat baik untuk terus meningkatkan dan mempertahnkan usahanya. Karena strategi pemasaran sangat perluh dilakukan pelaku UMKM terutama pada saat ini, pelaku UMKM harus benar-benar memikirkan strategi pemasaran yang dilakukan untuk meningkatkan usahanya di masa pandemic-19 ini. Pelaku UMKM di Desa Tawang hampir semua yang sudah diwawancarai menggunakan strategi pemasaran yang baik saat ini.

Dari hasil wawancara dan pengamatan yang sudah dilakukan produk UMKM yang bisa di jual online dan yang tidak bisa online yaitu antara lain:

a. Online

1) Kue Pia Matahari Kering 
Kue pia kering matahari ini dipasarkan di Marketplace Facebook (dipasarkan hanya khuss daerah Kediri, Surabay, Malang, Lamongan, Sidoarjo, dan diseluruh wilayah di Jawa Timur) dan di Shopee bisa sampai di seluruh Indonesia karena packingannya khusus packing jarak jauh.
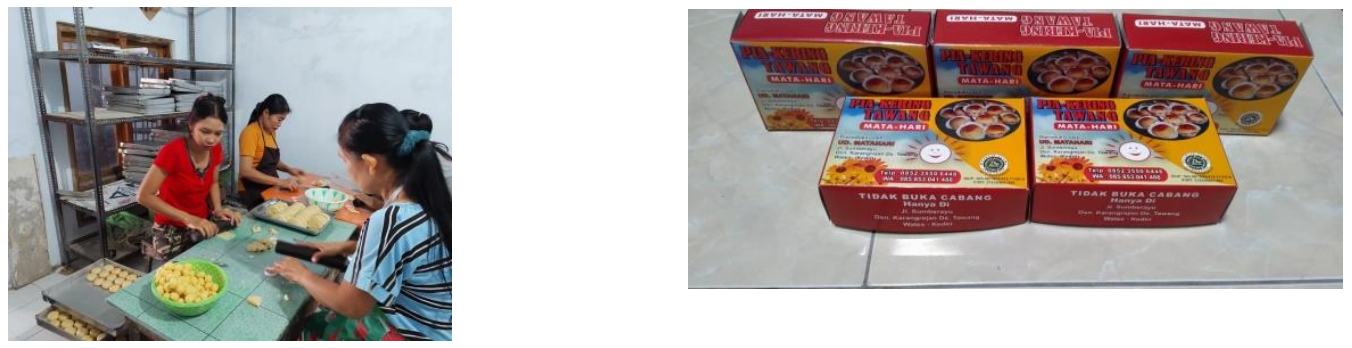

2) Gula Merah Tebu

Gula merah tebu ini dipasarkan di Marketplace Facebook dan di ambil pabrik-pabrik kecap untuk dijadian kecap.
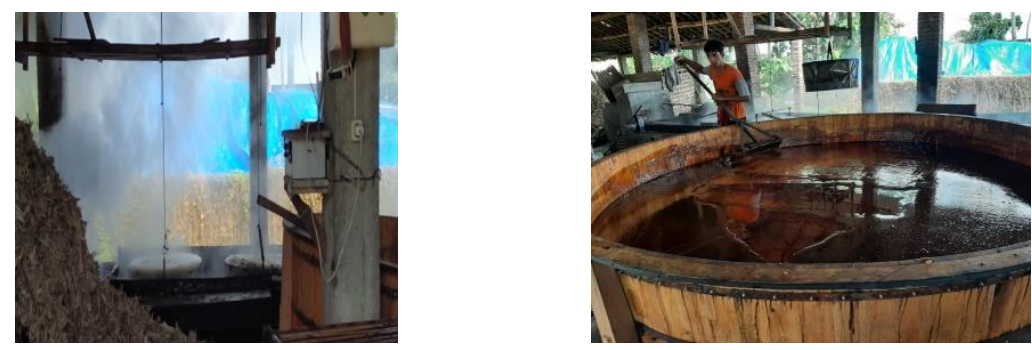

b. Offline

1) Es Puter

Es puter pak Ya'on ini dipasarkan offline yaitu dengan cara berkeliling di wilayah desa Tawang, karena dari hasil wawancara jika es puter ini dipasarkan online dengan menjual bahannya saja maka tidak akan laku karena tidak semua orang bisa membuat es puter tersebut.

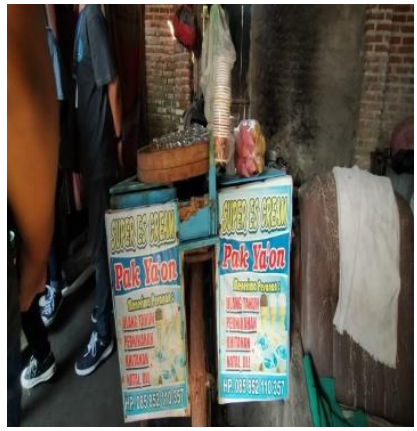

2) Penggorengan Krupuk

Penggorengan krupuk ini dipasarkan keliling karena dari hasil wawancara kepada penjualnya, penjualnya takut jika dikirim online nanti krupknya hancur atau sampai sana sudah tidak enak krupuknya.

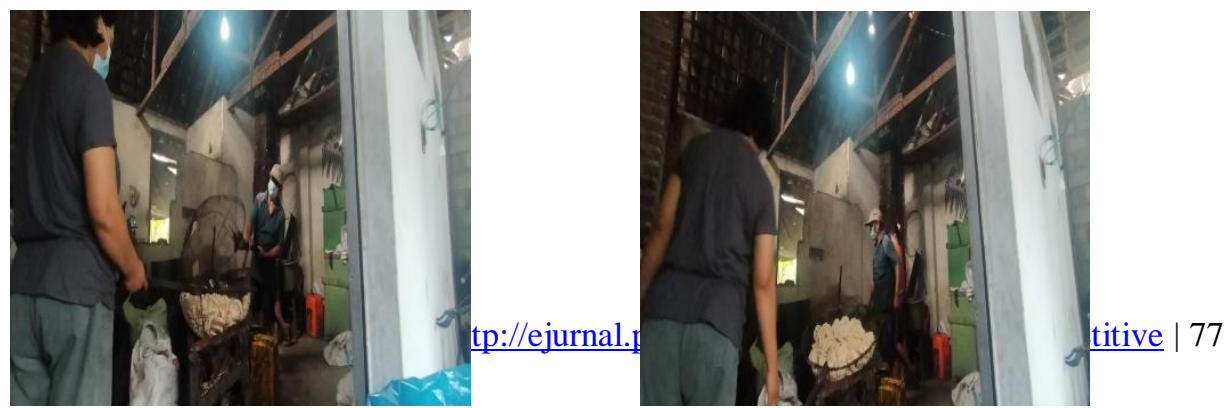


3) Pabrik Tahu

Pabrik Tahu ini sudah mempunyai penjual yang akan mengambil tahu ketempatnya jadi tidak perluh untuk dijual online. Dari hasil wawancara kata pemilik pabrik tahu jika tahu mentah dijual online pasti sampai sana sudah hancur dan bahkan tahu udah basi.
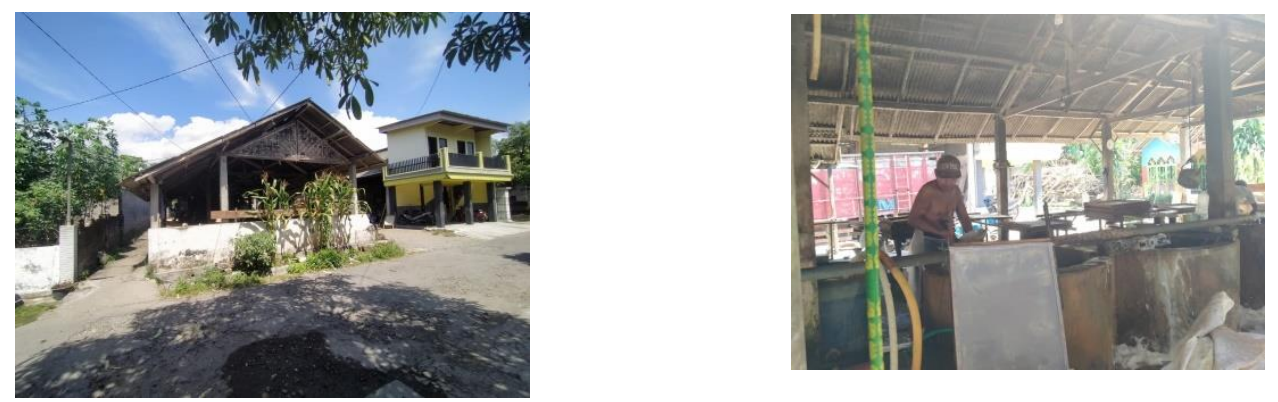

\section{KESIMPULAN}

UMKM di Desa Tawang Kecamatan Wates Kabupaten Kediri dapat diperoleh bahwa semua UMKM masih bisa bertahan di masa pandemic dengan berbagai cara yang dilakukan oleh pelaku UMKM untuk selalu dan tetap mempertahankan usahanya walaupun saat ini sedang terjadi pandemic covid-19. Dari hasil wawancara dan pengamatan pada UMKM di Desa Tawang semua UMKM menurunkan harga jual produknya agar tetap selalu bertahan pada saat ini. UMKM di Desa Tawang yang mempertahankan produknya dengan memanfaatkan media sosial itu sebanyak $30 \%$ yaitu meliputi penjual pia matahari kering, gula tebu, dll dan yang $70 \%$ yaitu meliputi es puter, penggorengan krupuk, pabrik tahu, dll yang saat ini berjualan keliling dan berjualan di pasar tetapi harga produknya samasama dikurangi. Alasan yang diperoleh saat melakukan wawancara yaitu agar saat ini UMKM yang dilakukan tetap bertahan dan selalu berkembang terus.

Beberapa strategi yang sudah dilakukan pelaku UMKM di Desa Tawang Kecamatan Wates Kabupaten Kediri adalah sebagai berikut yaitu yang pertama memanfaatkan sisi positif dari teknologi untuk menyebarluaskan produk dan yang kedua adanya pengurangan harga.

Strategi pemasaran yang dilakukan oleh pelaku UMKM di Desa Tawang Kecamatan Wates saat adanya pandemic covid-19 ini sudah sangat baik untuk terus meningkatkan dan mempertahnkan usahanya. Karena strategi pemasaran sangat perluh dilakukan pelaku UMKM terutama pada saat ini, pelaku UMKM harus benar-benar memikirkan strategi pemasaran yang dilakukan untuk meningkatkan usahanya di masa pandemic-19 ini. Pelaku UMKM di Desa Tawang hampir semua yang sudah diwawancarai menggunakan strategi pemasaran yang baik saat ini

\section{DAFTAR PUSTAKA}

Azizah, Fadilah Nur. Desember 2020. Strategi UMKM untuk Meningkatkan Perekonomian Selama Pandemi Covid-19 Pada Saat New Normal. Jurnal of Economics, Vol. 5, No. 1.

Arianto, Bambang. Desember 2020. Pengembangan UMKM Digital Di Masa Pandemi Covid-19. Jurnal Administrasi Bisnis, Vol. 6, No. 2. 
Priagani, Ade. Memperkuat Manajemen Pemasaran dalam Konteks Persaingan. Jurnal Kebangsaan, Vol. 2, No. 4.

Yanuar, Masnia Mahardi. Dampak Kualitas Produk, Harga, Promosi, Dan Kualitas Pelayanan Terhadap Kepuasan Pelanggan Optik Marlin Cabang Jember. Jurnal Manajemen Dan Bisnis Indonesia, Vol. 3, No. 1.

Wibowo, Dimas Hendika. Analisis Strategi Pemasaran Untuk Meningkatkan Daya Saing UMKM (Studi pada Bati Diajeng Solo). Jurnal Administrasi Bisnis (JAB), Vol. 29, No. 1.

Watie, Errika Dwi Setya. Komunikasi dan Media Sosial, Jurnal The Messenger, Vol. 3, No. 1, Juli 2011.

Rosmadi, Maskarto Lucky Nara. Maret 2021. Penerapan Strategi Bisnis di Masa Pandemi Covid-19. Jurnal IKRA-ITH Ekonomika, Vol. 4, No. 1.

UMKM, diakses di Kediri pada Tanggal 25 Juli 2021, Pukul 14:27 dari https://money.kompas.com/read/2021/03/36/153202726/apa-itu-umkm-pengertian-kriteriadan-contohnya?page=all\#page2 